\title{
LOVE PREREQUISITES IN PABLO NERUDA'S POEM IF YOU FORGET ME
}

\author{
Siti Khairunisa Zaluku, M. Manugeren \\ Faculty of Literature, Universitas Islam Sumatra Utara, Medan, Indonesia \\ e-mail: sitikhairunisah53@gmail.com
}

\begin{abstract}
The poem is one of Pablo Neruda's finest collections, containing undivided feelings for someone with picturesque comparisons with life and spiritual elements. The poem depicts a person's selfless and pure love for another. It is about two choices a boy has given to a girl, whether the girl will forget him or come to him. While the first half of the poem is incredibly romantic and flattering, the third and fourth stanzas paint a very different picture, and they serve as a warning to Neruda's mistress. The third stanza stands on its own, cautioning Neruda's lover that if she stops loving him, he will do the same in return. It also begins the first in a string of ultimatums Neruda offers to his lover. The study is conducted by means of descriptive qualitative method, showing social pictures, in this case matters of love. The grand theory used is taken from Steinberg's triangular theory of love. The results show that harmony in love could be obtained by means of intimacy, passion and commitment.
\end{abstract}

Keywords: passion, intimacy, commitment

\section{Introduction}

Ricardo Eliecer Neftalí Reyes Basoalto (Pablo Neruda) was born on July 12, 1904 in Parral (Chile). He is actually a Chilean poet-diplomat and politician and also known as one of the greatest Spanish-language poets of the 20th century. Neruda wrote his poems in a variety of styles, including surrealist poems, historical epics, overtly political manifestos, a prose autobiography, and passionate love poems such as the ones in his collection Twenty Love Poems and a Song of Despair. In 1971, Neruda was awarded the Nobel Prize in Literature. He died in Santiago on September 23, 1973, due to a prostate cancer.

If You Forget Me is one of his Twenty Love Poems and Song of Despair's collection. This poem was written when Pablo Neruda was in exile from Chile, during which time he also had an affair with Matilde Urrutia, the woman who then became his third wife. It is estimated that the poem was written for Matilde. This poem shows how when someone can take over your mind, everything you see, hear, touch, or naturally will remind you of that person. In this poem, Neruda also tells about the consequences if his lover stop loving him. Love can only last long when a relationship is cared for and not ignored. As soon as one person does not see it as important, the relationship begins to wither.

Based on the statement above, it can be seen that the fact is that love is conditional. There are love prerequisites that each person must have if they want to maintain their love relationship. The reason why the writer chooses the topic is because the prerequisites of 
love are important in a relationship. It is impossible for someone to fall in love with someone else without one condition. For example, there used to be a true story of a woman who was very beautiful, apparently willing to marry a man with a disability, could not stand and was only lying on his bed, his mouth always mumbling and drooling. Patiently the beautiful woman wiped the saliva of the disabled man. Wherever they are, the beautiful woman always takes the disabled man with a crib. One time there was someone who was curious and asked her why she wanted to marry the disabled man even though there were still many normal men out there and certainly well established. The very beautiful woman answered, "the reason why I want to marry him because I believe he is the one who will take me to heaven because I hear from his mouth that he never stops saying the holy verses of Allah." That is why the writer decides to analyze the love preresiquisites in this study.

\section{Literature Review}

\subsection{Love}

Scientifically, love is a biological process that forms a chemical reaction in our body. Love is influenced by the release of hormones, neurotransmitters. Hormone "Horman" which means "move", or in other words the hormone is the chemical messenger between cells or between groups of cells that can only spread in the body.

De Saint-Exupéry (1984) states that love does not consist of gazing at each other, but in looking outward together in the same direction. Hendrick and Hendrick (1989) says that none phenomenon can describe how love is, ultimately love is a complex set of emotional and mental states. Love is a strong affection for or attachment or devotion to a person or persons. It implies intense fondness or deep devotion and may apply to various relationships or objects. What distinguishes love from "affection" or "attainment" is that the feelings implied by the latter are not as powerful or deep as those implied by love. Also, love can be treated in a broad sense to mean the feeling of benevolence and closeness (or brotherhood) that people may have for each other. (Thisen, 1987: 31-53.)

Love is an expression of emotion that has the meaning to have each other, in need, mutual respect, the place to channel desires and so on related to love and ultimately lead to happiness between two people who like each other.

\subsection{Prerequisites of love}

Prerequisite is partly based on requirere, meaning "to need or require". So a prerequisite can be anything that must be accomplished or acquired before something else can be done. Possessing a valid credit card is a prerequisite for renting a car. A physical exam may be a prerequisite for receiving a life-insurance. So love prerequisites can be interpreted as conditions that are needed if you want to have a love relationship.

Sternberg (1988) puts forward a triangular theory of love, theory which states that there are three components in love, namely intimacy, passion, and commitment.

\subsubsection{Intimacy}

Intimacy refers to feelings of closeness, connectedness, and bondedness in loving relationships. It thus includes within its purview those feelings that give rise, essentially, to the experience of warmth in a loving relationship.

The following are examples of intimacy components in a relationship:

1) Intimate intense communication. 
2) A desire to make your partner happy.

3) Having a happy feeling when with a partner.

4) Understanding and supporting a partner's situation.

5) Trying to respect your partner and loved ones.

\subsubsection{Passion}

Passion refers to the drives that lead to romance, physical attraction, sexual consummation, and related phenomena in loving relationships. The passion component includes within its purview those sources of motivational and other forms of arousal that lead to the experience of passion in a loving relationship.

Indications in the element of passion include:

1. Sexual needs,

2. The desire and need to meet a partner to fulfill a passion,

3. Dominating each other,

4. Always thinking of loved ones,

5. Willing to sacrifice for the sake of a partner.

\subsubsection{Commitment}

Decision/commitment refers, in the short-term, to the decision that one loves a certain other, and in the long-term, to one's commitment to maintain that love. These two aspects of the decision/commitment component do not necessarily go together, in that one can decide to love someone without being committed to the love in the long-term, or one can be committed to a relationship without acknowledging that one loves the other person in the relationship.

The following are examples of forms of commitment:

1. Agreeing with a joint decision to establish a relationship.

2. Being able to overcome obstacles together.

3. Being able to maintain loyalty well.

4. Mutual trust and maintain trust between you and your partner.

\section{Research Method}

The research method used is qualitative research design. In qualitative research method, the data are taken from many texts and are then explored and analyzed using descriptive qualitative method since it intends to identify clauses, sentence and will be interpreted into the form of words rather than numbers (Creswell, 2013: 87). This is in line with the statement given by Johnson and Waterfield in Yi-Huey Guo (2019) that social constructs should be "interpreted" rather than "measured". In this case, the data are taken from Neruda's poem If You Forget Me, in the forms of lines of chosen stanzas.

In addition, this study also follows the theory of Siswantoro (2008) who claims that research data are collected by observation method, heuristic and hermeneutic reading. Observations are made by reading the poem repeatedly and carefully, so the researcher can comprehensively understand the whole text.

The procedures are as follows, Observation, Text elaboration, Identifying the data and collecting the theory relating to this analysis, Reading and understanding the content of the poem, Making important note based on prerequisites of love in the poem and Finding the points and describing how love prerequisites in the poem If You Forget Me are exposed. 
The data analysis technique used in this research is technique qualitative descriptive analysis by means of text reading (Siswantoro: 2008). After collecting data by understanding the contents of the poem, the researcher comes to the next step of this research that is to find to points of love prerequisites, focusing on the object of the research. In this section the step begins by finding out anything about love. The next step is finding the points of love prerequisites contained in the poem and then describing how love prerequisites are applied.

\section{Results and Discussion}

At the beginning of the poem, in the first stanza, Neruda only wrote one line "I want you to know one thing". If we interpret the sentence it will still raise questions to the reader, but when the sentence is combined with the title it will read "If you forget me, I want you to know one thing". Which means that in the first stanza Neruda gave a stern warning marked with the words "one thing" which was intended for anyone in the poem. And the meaning of this poem continues after the title of the poem "If You Forget Me." This poem tells what if later his girlfriend forgot him.

In the second stanza, Neruda revealed his feelings to his girlfriend was. "If I look at the crystal moon, at the red branch of the slow autumn at my window, if I touch near the fire the impalpable ash or the wrinkled body of the log, everything carries me to you," In this section Neruda revealed about his feelings to his girlfriend that time was spun for so long, and that was marked by the words "slow autumn" may be because he always thought of his girlfriend and whatever he sees and touches will end by reminded him of his girlfriend. The next line Neruda wrote "as if everything that exists, aromas, light, metals, were little boats that sail toward those isles of yours that wait for me." This section Neruda explains that he feels the particles around him are like intermediaries who bring him to his girlfriend who is waiting faithfully for him how he was then.

If the first and second stanzas use a low tone and are more likely to be romantic, another case with this third stanza if the situation is different. Neruda wrote "Well, now, if you stop loving me I shall stop loving you little by little". In this stanza Neruda explained the decision he would take if his girlfriend no longer loved him. He will also stop loving her because he thinks it is a useless thing.

The fourth stanza is still a continuation of stanza three. If suddenly you forget me don't look for me, for I shall already have forgotten you. He emphasizes that if his girlfriend forgets and doesn't need him anymore, then he will also forget her. In order to emphasize this even more, Neruda only includes that one thought into the stanza. It is interesting to note Neruda's diction in that last line "I shall already have forgotten you." He tells his girlfriend that if she suddenly forgets him, he wants her to know that he was the one who forgot first. It seems important to him that she knows it is she who was forgotten first.

In the fifth stanza, Neruda repeats his commitment to his girlfriend. This is confirmed by the words "and you decide to leave me at the shore "and "remember that on that day, at that hour, I shall lift my arms and my roots will set off to seek another land".

In the fifth stanza Neruda said in his poem that if his girlfriend was bored because of the very long wait, and left her where they first met and fall in love with, then at that moment Neruda said that she would throw away all of her dreams and memories to live together her lover and will look for a new girlfriend.

In the sixth and final stanza, however, Neruda changes his tone once again, this time returning to the romantic and passionate tone of the first stanza. The first line of the 
last stanza is comprised of a single word: "But." This gives the reader the impression that all that has been occurring in the previous stanzas has been setting the stage for this final one. It is as if the speaker is telling his lover, "If you do any of these things, I will do them back to you, but if you do not, this will happen instead," for the remaining lines of the final stanza reveal what will happen if the lover does not forget him. If, instead, she feels "...that you are destined for me," the feeling will be returned.

In the last stanza, Neruda compares his love for his girlfriend to a fire: it feeds off of the love his girlfriend has for him, and therefore, it can only be extinguished if her love dies. The speaker closes by vowing that as long as his lover lives, the love they share for each other will be cradled between them, in their arms.

\subsection{Love Prerequisites in the Poem}

This research covers the three points of love prerequisites adopted. They are, intimacy, passion, and commitment.

\subsubsection{Intimacy}

Intimacy refers to feelings of closeness, connectedness, and bond in loving relationships. It thus includes within its purview those feelings that give rise, essentially, to the experience of warmth in a loving relationship.

"If I look at the crystal moon, at the red branch of the slow autumn at my window, if I touch near the fire the impalpable ash or the wrinkled body of the log, everything carries me to you." (Neruda, 1952: 2)

The quote above is part of stanza 1, showing how much he loves his lover. He stated that whatever he saw and touched always reminded him of his lover. He even described his lover like a crystal moon, which means indirectly he praised the beauty of her. In this section Neruda revealed about his feelings to his girlfriend that time was spinned for so long, and that was marked by the words "slow autumn" may be because he always thought of his girlfriend and whatever he sees and touches will end by reminding him of his girlfriend.

"as if everything that exists, aromas, light, metals, were little boats that sail toward those isles of yours that wait for me." (Neruda, 1952: 2)

In this part, Neruda says again that it is as if everything in this world is an intermediary that makes him always want to be closer to his girlfriend and he feels the particles around him are like intermediaries who bring him to his girlfriend who is waiting faithfully for him how he was then.

\subsubsection{Passion}

Passion refers to the drives that lead to romance, physical attraction, sexual consummation, and related phenomena in loving relationships. The passion component includes within its purview those sources of motivational and other forms of arousal that lead to the experience of passion in a loving relationship. Even though in this poem there are no words that refer to sexual desire, but in the second stanza we can find that Neruda always thinks of his girlfriend.

"But if each day, each hour, you feel that you are destined for me with implacable sweetness, if each day a flower climbs up to your lips to seek me, ah my love, ah my own, in me all that fire is repeated, in me nothing 
is extinguished or forgotten, my love feeds on your love, beloved, and as long as you live it will be in your arms without leaving mine."

(Neruda, 1952: 6)

The sixth stanza explains the opposite of the third stanza to the fifth stanza. In this stanza, Neruda explained that if his girlfriend still wants to be with him forever, he will not leave and will continue with his girlfriend forever. In his poem, Neruda wrote that he could love his girlfriend in such a way if his girlfriend also loved him, and Neruda would love her very deeply. And his passion was expressed by the words "with implacable sweetness."

Neruda also expressed his happiness if his girlfriend always mentioned his name all the time. And that was marked by romantic words "if each day a flower climbs up to your lips to seek me." And he also said in his poem that as long as his girlfriend still loved him, he was sure that his love would never die and he would always remember it for the rest of their lives. It was marked because he compared "fire" in his poetry with his love.

\subsubsection{Commitment}

Decision/commitment refers, in the short-term, to the decision that one loves a certain other, and in the long-term, to one's commitment to maintain that love. These two aspects of the decision/commitment component do not necessarily go together, in that one can decide to love someone without being committed to the love in the long-term, or one can be committed to a relationship without acknowledging that one loves the other person in the relationship. Here are some quotes from poems that emphasize the element of commitment:

"Well, now, if little by little you stop loving me I shall stop loving you

little by little." (Neruda, 1952: 3)

The quote above is the first commitment to his girlfriend that if Neruda's girlfriend cannot commit to love him and even stop loving him then he also does the same, because he thinks it is a useless thing. In this stanza Neruda explained the decision he would taked if his girlfriend no longer loved him.

"If suddenly you forget me do not look for me, for I shall already have forgotten you." (Neruda, 1952: 4)

The above quote is a second commitment clearly stated by Neruda that if his lover does not need Neruda again in her life and decides to forget him, Neruda firmly says that he is the first person to forget his lover. In this stanza, Neruda only wants a commitment to be faithful in having a love relationship, to be responsible in loving, and to maintain love no matter what happens later.

"If you think it long and mad, the wind of banners that passes through my life, and you decide to leave me at the shore of the heart where I have roots, remember that on that day, at that hour, I shall lift my arms and my roots will set off to seek another land." (Neruda, 1952: 5)

Neruda once again give a commitment to his girlfriend as mention in the quote above. Neruda states that if his lover left him then he would immediately leave her at that moment. In the fifth stanza Neruda said in his poem that if his girlfriend was bored because of the very long wait, and left her where they first met and fall in love with, then at that 
moment Neruda said that she would throw away all of her dreams and memories to live together her lover and will look for a new girlfriend.

\section{Conclusion}

This poem contains three of the love prerequisites, commitment, intimacy, and passion based on the theory of Stenberg.

Commitment is about being with another person in a relationship, but love is not always necessary. A person may want to be with someone else because they have affection for them, or it may just be a feeling of comfort that motivates them. Being at ease with another person is part of a relationship, and this may suffice for someone to remain with their partner. If formal vows have been taken by the couple, a person may feel responsible for staying together. This does not necessarily signify love or caring, but it does form the basis of their commitment. Commitment is what holds a couple together through the ups and downs of life, but it does not necessarily signify love. Love is what makes a person want to keep their commitment no matter what happens, and this may fade in and out during the span of a relationship. Commitment and love combined make a great relationship, but each can form the basis of a working relationship on its own.

Intimacy usually denotes mutual vulnerability, openness, and sharing. It is often present in close, loving relationships such as marriages and friendships. The term is also sometimes used to refer to sexual interaction but intimacy does not have to be sexual. Intimacy can be vital to maintaining a healthy social life. If you avoid intimacy, you may find yourself isolated or in constant conflict with others. When fear of intimacy disrupts a relationship, couples counseling or individual therapy may help.

Passion is strong and barely controllable emotion. Passion is a very strong feeling about a person or thing. Passion is an intense emotion, a compelling enthusiasm or desire for something. Love is all about what you feel to care about, that comes along with affection, desire and pleasure. Whereas, Passion can be understand completely in adjective sense.

\section{References}

Creswell, J. W. (2013). Research Design: Pendekatan Kualitatif, Kuantitatif, dan Mixed. Yogyakarta: Pustaka Pelajar.

De Saint-Exupéry, A. (1984). Airman's Odyssey. New York: Reynal \& Hitchcock.

Hendrick, C., \& Hendrick, S. S. (1989). Research on love: Does it measure up? Journal of Personality and Social Psychology, 56, 784-794. http://dx.doi.org/10.1037/0022-3514.56.5.784.

Https://www.familyfriendpoems.com/poem/if-you-forget-me-by-pablo-neruda

Guo, Yi-Huey. (2019). Understanding the Genre Features of Qualitative Research: A Case Study. Language Literacy: Journal of Linguistics, Literature and Language Teaching Volume 3, Number 2. DOI: https://doi.org/10.30743/1l.v3i2.1674 https://jurnal.uisu.ac.id/index.php/languageliteracy/article/view/1674/pdf

Neruda, P. (1952). Los Versos Del Capitan: Poemas De Amor. https://www.espoesia.com/si-tu-me-ovidas-pablo-neruda/

Siswantoro. (2008). Metode Penelitian Sastra: Analisis Psikologi Sastra. Surakarta: Muhammadyah University Press.

Sternberg, R. J. (1988). The Triangle of Love: Intimacy Passion and Commitment. New York: Basic Books. 
Love Prerequisites in Pablo Neruda's Poem If You Forget Me, Siti Khairunisa Zaluku, M. Manugeren

Thisen, J. (1987). A Theory of Love in the Contemporary World. International Journal of Social Economics, Vol. 14 No. 12, pp. 31-53. https://doi.org/10.1108/eb014094 